\title{
Bridging the Knowledge Gap between Secondary and Higher Education
}

\section{Zorana Ercegovac}

This article suggests several intersections for possible collaboration among different educational levels and disciplines. It describes some of the collaborative work between a physics teacher and a librarian at a high school level. In particular, science-integrated information literacy competencies have been selected that may easily be mapped to, and extended for, higher education. The paper concludes with directions for further study and a crossover between information literacy standards for secondary schools and colleges.

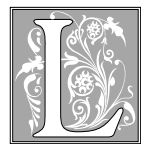

earning transitions among different educational levels can present multiple challenges and often require a comprehensive juxtaposition of professional partnerships across varied disciplinary traditions. Obvious examples include transitions from the elementary school to the middle school, from middle school to the high school, and from there to colleges, universities, and workplaces. Yet, students are often a single summer apart from the giant steps they need to make in their lifelong learning journey. This paper discusses important ways that educators must work together to help the students make these transitions seamlessly and enjoyably.

This article first outlines those areas where educational connections offer a potential for fruitful partnerships among different types of librarians and between librarians and their faculty. Next, it describes some of the collaborative work between a physics teacher and a librarian at a high school level. The focus is on selected information literacy (IL) competencies that might be extended to higher education learning contexts. This work grew out of the author's own involvement in IL programs at very different educational levels starting with college students in general (since 1991), with engineering college students in particular (since 1995), and with 7-12 grade students and teachers (since 1998). ${ }^{1-4}$ Finally, both sets of standards, Information Power and Information Literacy Competency Standards for Higher Education, are given side by side in appendix A..$^{5-6}$

\section{Educational Partnerships}

This article discusses four levels of partnership that are important in helping students make transitions from one educational level to the next seamlessly and meaningfully. Collaborative information literacy (IL) efforts between librarians and

Zorana Ercegovac is a Researcher in the Henry Samueli School of Engineering and Applied Sciences at the University of California, Los Angeles; e-mail: zercegov@ucla.edu. This study is supported in part by the Engineering Information Foundation grant EiF01.17 and in part by the Computer Science Department of the Henry Samueli School of Engineering and Applied Sciences at the University of California, Los Angeles. 
faculty in $\mathrm{K}-12$ schools and in colleges are relatively well represented in the reviewed literature. This activity is illustrated in cells C and A, respectively, of figure 1 . However, less activity on partnerships has been seen among librarians from different educational levels (cell B). Reports on team efforts between secondary school teachers and their counterparts in higher education go under the head- ings of school-university partnership, inservice training, capacity building, and access to education (cell D).

\section{Librarian-Faculty Partnerships}

There is a rich body of literature about IL partnerships for college librarians and, separately, for school librarians. Each informs its predominant group of readers about examples of partnership in various

\begin{tabular}{|c|c|c|}
\hline \multicolumn{3}{|c|}{$\begin{array}{l}\text { FIGURE } 1 \\
\text { Spaces for Potential Collaborative Work Abound } \\
\end{array}$} \\
\hline & K-12 LIBRARIANS & COLLEGE FACULTY \\
\hline \multirow{3}{*}{$\begin{array}{l}\text { COLLEGE } \\
\text { LIBRARIANS }\end{array}$} & Type B Collaboration & Type A Collaboration \\
\hline & $\begin{array}{l}\text { Early progress has been made. } \\
\text { See, for example, the oint Task } \\
\text { Force that was established in } \\
1998 \text { by AASL and ACRL: }\end{array}$ & $\begin{array}{l}\text { For an overview of this type of } \\
\text { activity, readers are referred to, } \\
\text { for example; }\end{array}$ \\
\hline & $\begin{array}{l}\text { "Blueprint for Collaboration: } \\
\text { AASL/ACRL Task Force on the } \\
\text { Educational Role of Libraries" } \\
\text { (http://www.ala.org/acrl/ } \\
\text { blueprint.html) }\end{array}$ & $\begin{array}{l}\text { "A Collaboration/Team } \\
\text { Building Bibliography," by } \\
\text { ACRL, covers case studies } \\
\text { since } 1984 \text { focusing on the } \\
\text { studies in 1990s (http:// } \\
\text { www.csusm.edu/acrl/il/ } \\
\text { collabbiblio.html). }\end{array}$ \\
\hline \multirow[b]{2}{*}{ K-12 FACULTY } & Type C Collaboration & Type D Collaboration \\
\hline & $\begin{array}{l}\text { Some progress has been made } \\
\text { and reported mainly in school } \\
\text { library literature. See, for } \\
\text { example, the following } \\
\text { resources: } \\
\text { Reports are published by } \\
\text { libraries, museums, and } \\
\text { archives, such as Library of } \\
\text { Congress American Memory } \\
\text { lessons, http://memory.loc.gov/ } \\
\text { ammem/ndlpedu; the } \\
\text { Smithsonian Institution, the } \\
\text { National Archives and Records } \\
\text { Administration; http:// } \\
\text { www.archives.gov/ } \\
\text { digital_classroom/; or the } \\
\text { Exploratorium science program } \\
\text { at http://www.exploratorium.org. }\end{array}$ & $\begin{array}{l}\text { School-university partnerships } \\
\text { are described in Dodge 1997; } \\
\text { Lee 1999; NSF 1999; Oakes } \\
\text { and Lipton 1999; The Texas } \\
\text { A\&M University (http:// } \\
\text { partnerships.tamu.edu/ } \\
\text { default.asp); University of } \\
\text { California at Berkeley (http:// } \\
\text { k12.ucop.edu). }\end{array}$ \\
\hline
\end{tabular}


academic disciplines and interdisciplinary topics. Each reports challenges that librarians are facing with regard to powerful and evolving technologies, new software releases, accreditation standards, and user studies. College librarians learn about important efforts in team building from case studies that are typically published in College $\mathcal{E}$ Research Libraries, Research Strategies, Reference Librarian, Reference Services Review, The Journal of Academic Librarianship, and Issues in Science E Technology Librarianship, to mention just the most prevalent titles (cell A in figure 1). Many library schools offer graduate courses in bibliographic instruction; bibliographies on specific types of team building also are useful. ${ }^{78}$ While writing this paper, the author came across the OCLC White Paper on the Web-based information patterns of U.S. college students. ${ }^{9}$ The report suggests numerous areas that require attention, including access to sources, customer orientation in general, and instructional services, in particular.

Examples of $\mathrm{K}-12$ grade IL partnerships are found in the equally rich literature that is typically reported in School Library Media Research, School Library Journal, Knowledge Quest, Educational Leadership, and Teacher, among other technology-related and discipline-related sources (cell C in figure 1). Anecdotal knowledge sheds light that college librarians try to keep current with their own readings, conferences, listservs, and, understandably, find little time to read school library literature. This author informally interviewed dozens of school librarians at state and regional conferences (e.g., California School Library Association) and found that school librarians, too, have little time to regularly read their own magazines and to attend workshops and conferences, let alone to read college and research library literature on IL issues.

Although some progress has been made where librarians have partnered with faculty to create integrated IL programs for their students, the potential for various educational intersections has just been recognized as an important component in the transfer of knowledge from one educational level to the next. In this direction, some collaboration between college and school librarians has only recently been witnessed (cell B in figure 1).

\section{College Librarian-School Librarian Partnerships}

A series of recent events has been representative of this type of interest. The Association of College and Research Libraries and the American Association of School Librarians created a Task Force on the Educational Role of Libraries. ${ }^{10}$ The task force recommended four areas in which K-16 librarians could work together. These included various forms of collaboration, joint association activities, continuing education for librarians, and outreach projects among libraries, school districts, and colleges of education.

The March/April issue of Knowledge Quest has devoted its attention entirely to this topic: "One step beyond: From high school to college."11,12 In addition, various agencies and professional organizations have expanded their efforts and funding in the K-16 programs (e.g., National Science Foundation [http://www.nsf.gov/], Association for Computing Machinery K12 Task Force [http://www.acm.org/education/k12/], and its Special Interest Group on Computer Science Education [http://www.acm.org/sigcse]). This author spoke at several workshops and state annual conferences on "Survival skills: What every high school senior ought to know before entering college?" She also participated in the High School and Beyond Panel titled "Did they forget what they learned in high school?" at the 2002 Annual Meeting of the Association of Independent School Librarians, in Pasadena, California.

Although many collaborative opportunities exist, there are barriers that may hamper such partnerships. Gloria Leckie and Anne Fullerton, for example, describe tensions, or "pedagogical discourses," that exist between college librarians and their faculty. ${ }^{13}$ Some of their findings include 
arguments on the part of faculty that there is no time for IL units to be integrated in already overcrowded disciplines; another seems to be faculty's lack of willingness to give up any intellectual space to library instruction. Leckie and Fullerton suggest a number of possible roles for instructional librarians in partnering with their faculty (e.g., as personal liaisons with departments, as collaborators, leaders, mentors, and supporters).

This author's personal experience has

\section{Various curriculum standards competencies, \\ analogous, often published different sources, librarians.}

been that teacher-librarian partnerships are likely to be more successful at the middle school rather than the high school level. Middle school teachers (grades 78 ) may be more relaxed in terms of scheduling their lesson units and more interested in collaborative projects than are the high school teachers (grades 9-12). It also may be easier to integrate IL units into social studies rather than into the sciences where activities in labs often overpower those in libraries.

\section{School-University Partnerships}

The collaboration among teachers at various educational levels is little published in library literature (cell D in figure 1). Reports are mainly targeted to teachers and found in journal titles such as Teaching Education, Urban Education, Peabody Journal of Education, Education and Urban Society, Social Education, and Computers in the Social Studies. Many reports are available through the ERIC document service. Collaborative efforts are directed toward supporting schools with evaluation tools, educational programs, and instructional technology; numerous outreach programs foster the college-going culture and concern themselves with educational equity and policy. ${ }^{14-17}$

More attention must be paid to actively participating in teaching classroom teachers and working with school and public librarians. Natural seed themes would be to help them integrate critical thinking into their lesson plans and to help design assessment instruments to measure students' IL skills before and after library interventions. This type of cross-training is useful if a more coherent teaching structure is to be created across the board.

The following section discusses some of the IL aspects that worked well with high school students and could be mapped to IL programs for college students.

\section{Information Literacy Skills for Science Lessons}

Some interest is just beginning to be seen in collaborative work between college librarians and school librarians, as illustrated in cell B in figure 1, between school librarians and teachers (cell C), and between school and college faculty (cell D). Various curriculum standards and related competencies, though analogous, are often reported and published in different sources, and read by teachers and separately by librarians. However, one is often reminded that students become information literate when teachers and librarians together guide the students through discipline-related projects. For that to happen, some unification also is needed in IL programs between and among school and academic librarians, as well as between school and college faculty.

This author has reviewed just a few core IL competencies that appear to be important for all students, especially in preparing them for science and engineering college majors. These are based on the two sets of standards in information literacy as well as science curricular standards for 9-12 grade levels. ${ }^{18-21}$ Examples will be drawn from conceptual physics lesson units that are reported elsewhere. ${ }^{22}$

\section{Helping the Students Getting Started with Conceptual Maps}

Novices at any educational level are likely to be unfamiliar with the domain of their new topic or a given inquiry. Students 
often have a vague understanding of the concepts and terms they need to search under. To clarify search space as a whole, Ercegovac and Milling have had ninthgrade physics students use conceptual maps during their presearching phase. ${ }^{23}$ Conceptual maps are used as learning and teaching tools that include phrases represented as nodes and placed in ovals or rectangles. The connecting lines between the nodes stand for relationships that exist between the nodes. ${ }^{24}$

\section{A Case Study}

Following is a typical sequence of learning events during the presearching phase. On the topic of energy transformation, students are presented with terms, including chemical energy, combustion, conservation of energy, decay, engine, expansion of gas, force, fossil fuels, fusion, gasoline, heat, kinetic energy, light, motion, nuclear, potential energy, rock layers, the Sun, and work. Before they walk into the physics lab, the students learn concepts and terms using previous knowledge of acceleration and force. They search both printed sources (textbooks, science and physics dictionaries, handbooks, encyclopedias) and online sources, including Encyclopedia Britannica on the Web (http://school.eb.com). Students are reminded that many of the basic searching techniques they learned in lessons on online library catalogs (Boolean operators, truncation, modification, and selection of search words) are applicable to searching in general. In small groups, students search terms in a variety of sources. As the terms become clearer, students are asked to create their own conceptual map on energy transformation. They cluster terms into major concepts: types of energy (kinetic, potential, chemical, nuclear, heat, light), carriers of energy (gasoline, light, motion of car, heated gas), places where energy is transformed (plants, the Sun, engine, rock layers), and transformation process (decay, photosynthesis, fusion, combustion, gas expansion). Major concepts are color coded, placed into the ovals, and con- nected with arches. Finally, students label arches that describe relationships among the ovals. The process is demanding, iterative, collaborative, and noisy. Students learn to use various skills from everyday experiences, the sciences, visual and spatial aesthetics, technology, and group dynamics.

While students learn about the assigned topic, they also learn how to plan and collaborate before they "go online." These skills are consistent with the nformation Literacy Competency Standards for Higher Education and the nformation Power. Specifically, students use a variety of reference sources to identify key concepts and terms that describe their assigned topic. By getting a feel for the territory, they are more competent to plan and control their search.

\section{What Matters in Science Communication: From Secondary to Higher Education?}

Basic IL units typically introduce library catalogs that give access to books, reference sources, atlases, and other similar publications. Students also hear a lot about various ways to search and evaluate Web sources. They become exposed to periodical literature that gives access to journals, magazines, newspapers, bulletins, and other serial publications. This is all helpful to the students in a variety of disciplines. In addition, students at all levels have heard about the importance of giving credit to ideas and authors that they include in their own reports and presentations and about the mechanics of doing so, that is, how to write bibliographies.

What they do not necessarily learn is about the culture of making science, of inventing, communicating personally and in published literature, protecting their ideas and inventions, being rewarded, and working in teams within social and political contexts. In this regard, the following resources are of special importance to the students. The three groups of sources briefly discussed here include information about patents and trademarks, primary sources, and factual data. 
- Patents and trademarks offer an excellent basis for a variety of interdisciplinary projects. Students are introduced to the history of patents in the United States, the importance of patents and intellectual property, the differences between a patent and a trademark, and how to search each in the United States Patent and Trademark Office (http://www.uspto.gov). The office has developed a variety of educational outreach programs, including Museum, National Inventors Hall of Fame, and Project XL at http://www.uspto.gov/main/ outreach.htm.

- Primary sources are discussed within the context of a general information life cycle, including some basic knowledge about funding agencies, proposing research to be carried out, and reporting results back to the funding agency. Examples of excellent contributions on Morse, Edison, or Bell, are selected from the American Memory Project (http://memory.loc.gov/ammem). Connections are made with local school archives and collections. Students are introduced to the concepts of appraisal, archival organization, preservation, and with digital collections at the National Archives and Records Administration (http:// www.archives.gov) and the Smithsonian Archives (http://americanhistory.si.edu/archives/d-1.htm).

- Factual sources may be both science specific and of general application to science projects. An example of the former is the database on Material Safety Data Sheets (http://www.ilpi.com/msds), various databases by the Environmental Protection Agency (e.g., Toxic Release Inventory from http://www.epa.gov/tri, and the National Aeronautics and Space Administration from http://www.nasa.gov/ kids.html). An example of the latter is the U.S. Census (http://www.census.gov/). MSDS are discussed in several projects. In an environmental course, students brainstorm "five W's": what is the waste, where is it created, when it is created, why is it created, and what can be changed. In this and other learning settings, students use rich census data that allow them to track populations, and plot them on online maps (mapping engine that uses 1998 TIGER/ Line data ${ }^{\circledR}$ and 1990 Decennial Census data). Students use the EPA's Toxic Release Inventory database to track wastes in a given state or county on selected chemical emissions as these are released into the air, water, and soil.

Many of these information literacy experiences may be directly transferred to the Information Literacy Competency Standards for Higher Education. For example, work with conceptual mapping is directly related to Standard 1 (performance indicators 1.e and 4.a) and Standard 2 (indicator 2.b and 2.c). The awareness of patents, primary sources, and factual sources is related to Standard 1 (performance indicator 2) as well as to Standard 2. Finally, basic search techniques, elements of critical thinking, and bibliographical validity are applied throughout different sources and systems and provide a solid base to build on and to customize for different learning levels.

\section{Bridges administrative transitions students through.}

In addition to the librarians' roles that Leckie and Fullerton suggested, Ercegovac and Milling's experience in making IL units work at a secondary school level are summarized in the following four models:

1. Become a classroom teacher yourself and weave through your lessons and projects as many IL experiences as you wish. This model may not be as easy to implement at a college level; exceptions are schools and programs for biomedical and chemical informatics where the nature of programmatic synergy demands a mix of expertise (e.g., http:// www.informatics.indiana.edu).

2. Teach the teachers about specific ways they can empower their lessons with high IL content. This model may be enhanced if presented at conferences for teachers, archivists, museum curators, and administrators and not just at library conferences. At a college level, this model may be modi- 
fied to research and teaching assistants, project leaders, visiting and new faculty. Some faculty members might want to be "briefed" on selected technological innovations; research panels might be used to bring together faculty and librarians to discuss issues of mutual interest.

3. Prepare IL material and advertise in many different formats, media, and places. The material may be printed out or published on the Web; materials may be advertised through the home department, personally, electronically, in newspapers, elevators, bookmarks, posters, and newsgroups. The material is likely to receive higher attention if it relates to proposed research projects or the existing research thrusts. Involve the faculty in this process, ask for their feedback, and revise the material accordingly.

4. Speak the teacher's language. This model is well practiced among college librarians, who themselves often hold advanced degrees in various disciplines. Examples are law librarians, medical and science librarians, and business school librarians.

\section{Concluding Remarks}

This article identified educational intersections between librarians and faculty as reported in the open literature. It briefly mentioned more traditional types of partnerships, those in which librarians have collaborated with their faculty. In particu- lar, the article pointed to the two areas of potential partnership that have not been explored sufficiently. Working groups between school and academic librarians have just started to be seen. Each group can learn from another about IL programs, student characteristics and preferences, and different learning cultures. In addition, there is plenty of space for librarians to be included in school-university partnerships. This area ought to be further examined and developed.

Next, the article discussed some IL components for secondary schools that are standard based, inquiry driven, and resource rich. Each source is tied to students' everyday experiences, lab demonstrations, and high cognitive demands. Some of these elements may be transferred directly to college IL-integrated curricula. For comparison purposes, two sets of IL standards are given side by side in appendix A.

Bridges need to be built among administrative transitions that all students go through. The most fragile boundaries appear to be at the connecting lines, as students change their familiar schools, teachers, programs, and environments. These are between grades 6 and 7 (from elementary to middle school), between grades 8 and 9, and especially between the senior high school, and college freshmen. These educational areas are less studied, yet they offer promising partnerships among the existing capacities.

\section{Notes}

1. Zorana Ercegovac, "Information Access Instruction $\left(\mathrm{IAI}^{4}\right)$ : Design Principles," College $\mathcal{E}$ Research Libraries (May 1995): 249-57.

2. - - - "Accessing Global Information for Engineers," in: Proceedings of the $64^{\text {th }}$ Annual Meeting of the American Society for Information Science and Technology, Washington, D.C., Oct. 31Nov. 4, 2001 (Medford, N.J.: Information Today, published for ASIST, 2001).

3. - - - Information literacy: Search Strategies, Tools, and Resources for High School Students (Worthington, Ohio: Linworth, 2001). Description is available online from http://www.cs.ucla.edu/ Leap/zer/books.htm.

4. Zorana Ercegovac and Marcus Milling, "Aligning Science Learning Outcomes with IL Power," presented as a poster session at the 2002 Annual Conference of the Special Libraries Association, the Chemical Division, Los Angeles, June 11, 2002. Available online from http:// www.cs.ucla.edu/Leap/zer/sla.htm.

5. American Association for School Librarians and Association for Educational Communications and Technology, Information Power: Building Partnership for Learning (Chicago and London: ALA, 1998).

6. Association of College \& Research Libraries, Information Literacy Competency Standards for Higher Education (Chicago: ACRL, 2000). 
7. American Association of College \& Research Libraries. 2002. "A Collaboration/Team Building Bibliography." Available online from http://www.ala.org/acrl/il/collabbiblio.html.

8. Hannelore B. Rader, "Faculty-Librarian Collaboration in Building the Curriculum for the Millennium - the US Experience," presented at the $64^{\text {th }}$ IFLA General Conference, August 16-21, 1998 (Amsterdam: International Federation of Library Associations and Institutions, Annual Conference, 1998).

9. "OCLC White Paper on the Information Habits of College Students: How Academic Librarians Can Influence Students' Web-based Information," June 2002. Available online from http:/ /www2.oclc.org/oclc/pdf/printondemand/informationhabits.pdf.

10. Association of College \& Research Libraries and American Association of School Librarians, "Blueprint for Collaborating: AASL/ACRL Task Force on the Educational Role of Libraries." 2000. Available online from http://www.ala.org/acrl/blueprint.html.

11. American Association of School Librarians, Knowledge Quest, One Step Beyond: From High School to College. The entire March/April 2002 issue features articles about this important topic. Available online from http://www.ala.org/aasl/.

12. Ellysa Stern Cahoy, "Will Your Students Be Ready for College? Connecting K-12 and College Standards for Information Literacy," Knowledge Quest 30 (Mar./Apr. 2002): 12-15.

13. Gloria Leckie and Anne Fullerton, "The Roles of Academic Librarians in Fostering a Pedagogy for Information Literacy," ACRL Ninth National Conference, April 8-11, 1999, Detroit. Available online from http://www.ala.org/acrl/leckie.pdf.

14. Lina Lee, "Partners in Pedagogy: Collaboration between University and Secondary School Foreign Language Teachers," ERIC Clearinghouse on Languages and Linguistics (Washington, D.C.: ERICCL\&L, 1999). ERIC ED435186.

15. National Science Foundation, "Transition from Childhood to the Workplace (TCW)," Project Research Tomorrow: Conference on Children's Learning in MSE, Donaldson Brown Continuing Education Center, Blacksburg, Va., October 22-23, 1999.

16. Jeannie Oakes and Martin Lipton, Teaching to Change the World, $1^{\text {st }}$ ed. (Boston: McGrawHill College, 1999).

17. Bernard J. Dodge, "School-University Partnerships and Educational Technology," Computers in the Social Studies 5 (July/Aug. 1997). Available online from http://www.webcom.com/ journal/dodge.html. The paper also is available from the ERIC Clearinghouse on Information Resources, Syracuse, N.Y., June 1993. ERIC ED358840.

18. American Association for the Advancement of Science and National Science Teachers Association, Atlas of Science Literacy Project 2061 (Washington, D.C.: AAAS and NSTA, 2001).

19. National Assessment Governing Board, U. S. Department of Education, Science Framework for the 1996 and 2000 National Assessment of Educational Progress (Washington, D.C.: The Department [n.d.]). Available online from http://www.nagb.org/pubs/96-2000science/toc.html.

20. National Science Education Standards (Washington, D.C.: National Academy Press, 2001).

21. National Science Teachers Association, NSTA Pathways to the Science Standards: Guidelines for Moving the Vision into Practice, high school edition, ed. Juliana Texley and Ann Wild (Arlington, Va.: NSTA, 1996).

22. Zorana Ercegovac, "Mapping of Physics Content Standards to Information Literacy Standards: Collaboration for Powerful Lessons." (Paper is being reviewed.)

23. Ercegovac and Milling, "Aligning Science Learning Outcomes with IL Power."

24. Conceptual maps are used as learning and teaching tools for organizing and representing knowledge visually. The Institute for Human and Machine Cognition of the University of West Florida has published a bibliography with more than 210 publications, including journal and conference papers, books, and reports on the topic of conceptual maps. Available online from http://cmap.coginst.uwf.edu/refs.html. For an overview paper on conceptual maps, readers are referred to the article by Joseph D. Novak, "The Theory Underlying Concept Maps and How to Construct Them," published by the Institute for Human and Machine Cognition. Available online from http://cmap.coginst.uwf.edu/info/. 


\begin{tabular}{|c|c|c|c|}
\hline \multicolumn{4}{|c|}{$\begin{array}{c}\text { APPENDIX A } \\
\text { Information Power (AASL \& AECT, 1998) meets Information Literacy Competency Standards for Higher Education (ACRL, 2000) }\end{array}$} \\
\hline $\begin{array}{l}\text { AASL } \\
\text { standards } \\
\text { http://www.a- } \\
\text { la.org/aasl/ip- } \\
\text { nine.html }\end{array}$ & $\begin{array}{l}\text { Performance } \\
\text { indicators }\end{array}$ & $\begin{array}{l}\text { ACRL standards } \\
\text { http://www.ala.org/ac- } \\
\text { rl/ilstandardlo.html }\end{array}$ & Performance indicators \\
\hline $\begin{array}{l}\text { Standard } 1 \\
\text { The student } \\
\text { who is } \\
\text { information } \\
\text { literate } \\
\text { accesses } \\
\text { information } \\
\text { effectively and } \\
\text { efficiently. }\end{array}$ & $\begin{array}{l}\text { \#1 Recognizes the } \\
\text { need for information. } \\
\text { \#2 Recognizes that } \\
\text { accurate and } \\
\text { comprehensive. } \\
\text { information is the } \\
\text { basis for decision } \\
\text { making. } \\
\text { \#3 Formulates } \\
\text { questions based on } \\
\text { information need } \\
\text { \#4 Identifies a variety } \\
\text { of potential sources of } \\
\text { information. } \\
\text { \#5 Develops and uses } \\
\text { successful strategies } \\
\text { for locating } \\
\text { information. }\end{array}$ & $\begin{array}{l}\text { Standard } 2 \text { The student } \\
\text { who is information } \\
\text { literate accesses needed } \\
\text { information effectively } \\
\text { and efficiently. } \\
\text { Standard } 1 \text { The } \\
\text { information-literate } \\
\text { student determines the } \\
\text { nature and extent of } \\
\text { the information needed. }\end{array}$ & $\begin{array}{l}\text { \#1.e. [Student] identifies key concepts \& terms } \\
\text { that describe the information need. } \\
\text { \#2 Student identifies a variety of types and } \\
\text { formats of potential sources of information. } \\
\text { \#3 Student considers the cost and benefits of } \\
\text { acquiring info, defines a realistic overall plan and } \\
\text { time line to acquire the needed information. } \\
\text { Standard } \mathbf{2} \text { \#2.b. Identifies keywords, synonyms, } \\
\text { and related terms ... } \mathbf{2 . d .} \text {. Student constructs ... } \\
\text { search strategies (eg., search vocabulary, Boolean } \\
\text { operators...) } \\
\text { \#4 Refines strategy, if necessary. }\end{array}$ \\
\hline
\end{tabular}




\begin{tabular}{|c|c|c|c|}
\hline \multicolumn{4}{|c|}{$\begin{array}{l}\text { APPENDIX A } \\
\text { Information Power (AASL \& AECT, 1998) meets Information Literacy Competency Standards for Higher Education (ACRL, 2000) }\end{array}$} \\
\hline $\begin{array}{l}\text { AASL } \\
\text { standards }\end{array}$ & Performance indicators & ACRL standards & Performance indicators \\
\hline $\begin{array}{l}\text { Standard } 2 \\
\text { The student } \\
\text { evaluates } \\
\text { information } \\
\text { critically and } \\
\text { competently. }\end{array}$ & $\begin{array}{l}\text { \#1 Determines accuracy, relevance, } \\
\text { comprehensiveness. } \\
\text { \#2 Distinguishes among fact, point } \\
\text { of view, and opinion. } \\
\text { \#3 Identifies inaccurate and } \\
\text { misleading info. } \\
\text { \#4 Selects information suitable to the } \\
\text { problem/question. }\end{array}$ & $\begin{array}{l}\text { Standard } 3 \text { Student } \\
\text { evaluates information } \\
\text { and its sources critically } \\
\text { and incorporates selected } \\
\text { information into own } \\
\text { knowledge, values. }\end{array}$ & $\begin{array}{l}\text { \#1 Summarizes the main ideas. } \\
\text { \#2 Recognizes biased } \\
\text { information. } \\
\text { \#3-7 Synthesizes, determines } \\
\text { probable accuracy by evaluating } \\
\text { sources, applies technology, } \\
\text { reassesses the initial query and } \\
\text { revises. }\end{array}$ \\
\hline $\begin{array}{l}\text { Standard } 3 \\
\text { Student who is } \\
\text { information } \\
\text { literate uses } \\
\text { information } \\
\text { accurately, and } \\
\text { creatively. }\end{array}$ & $\begin{array}{l}\text { \#1 Organizes info for practical } \\
\text { applications. } \\
\text { \#2 Integrates new information into } \\
\text { one's own knowledge. } \\
\text { \#3 Applies info in critical thinking } \\
\text { and problem solving. } \\
\text { \#4 Produces and communicates info } \\
\text { in appropriate format. }\end{array}$ & $\begin{array}{l}\text { Standard } 4 \text { Student uses } \\
\text { information effectively to } \\
\text { accomplish a specific } \\
\text { purpose. }\end{array}$ & $\begin{array}{l}\text { Standard } 2 \\
\text { \#5 Student extracts, records, } \\
\text { and manages the information } \\
\text { (eg., syntax of a citation for } \\
\text { different resources). }\end{array}$ \\
\hline
\end{tabular}




\begin{tabular}{|c|c|c|c|}
\hline \multicolumn{4}{|c|}{$\begin{array}{c}\text { APPENDIX A } \\
\text { Information Power (AASL \& AECT, 1998) meets Information Literacy Competency Standards for Higher Education (ACRL, 2000) }\end{array}$} \\
\hline $\begin{array}{l}\text { AASL } \\
\text { standards }\end{array}$ & Performance indicators & ACRL standards & Performance indicators \\
\hline $\begin{array}{l}\text { Standard } 8 \\
\text { (from the social } \\
\text { responsibility } \\
\text { standards) } \\
\text { Student who is } \\
\text { information } \\
\text { literate } \\
\text { practices ethical } \\
\text { behavior in } \\
\text { regard to } \\
\text { information } \\
\text { and info } \\
\text { technology. }\end{array}$ & $\begin{array}{l}\text { \#1 Respects the principle of } \\
\text { intellectual freedom. } \\
\text { \#2 Respects intellectual property } \\
\text { rights } \\
\text { \#3 Uses information technology } \\
\text { responsibly. }\end{array}$ & $\begin{array}{l}\text { Standard } \mathbf{5} \\
\text { Student demonstrates } \\
\text { many of the economic, } \\
\text { legal, and social issues } \\
\text { surrounding the use of } \\
\text { info and accesses and } \\
\text { uses information ethically } \\
\text { and legally. }\end{array}$ & $\begin{array}{l}\text { \#1 Student discusses issues } \\
\text { related to censorship and } \\
\text { freedom of speech. } \\
\text { \#2 Participates in electronic } \\
\text { discussions following accepted } \\
\text { practices; uses approved } \\
\text { passwords for access to info } \\
\text { sources; complies with } \\
\text { institutional policies. }\end{array}$ \\
\hline
\end{tabular}

